\title{
Faith and Hermeneutics: Pragmatism versus Pragmatism
}

\section{Citation}

Simpson, James. 2003. Faith and hermeneutics: Pragmatism versus pragmatism. Journal of Medieval and Early Modern Studies 33(2): 215-39.

\section{Published Version}

http://dx.doi.org/10.1215/10829636-33-2-215

\section{Permanent link}

http://nrs.harvard.edu/urn-3:HUL.InstRepos:2643651

\section{Terms of Use}

This article was downloaded from Harvard University's DASH repository, and is made available under the terms and conditions applicable to Other Posted Material, as set forth at http:// nrs.harvard.edu/urn-3:HUL.InstRepos:dash.current.terms-of-use\#LAA

\section{Share Your Story}

The Harvard community has made this article openly available.

Please share how this access benefits you. Submit a story.

Accessibility 


\title{
Faith and Hermeneutics: Pragmatism versus Pragmatism
}

\author{
James Simpson \\ Girton College, University of Cambridge \\ Cambridge, United Kingdom
}

\begin{abstract}
When a man's verses cannot be understood, nor a man's good wit seconded with the forward child Understanding, it strikes a man more dead than a great reckoning in a little room.
\end{abstract}

-As You Like It, 3.3.10-13

In his Proslogion, written 1077-78, Anselm proposed his ontological argument for the existence of God as a proof demanding nothing other than itself. He states the argument in chapter 2; he introduces it in chapter 1, which ends thus: "neque enim quaero intelligere ut credam, sed credo ut intelligam" [for I do not seek to understand in order that I might believe; rather I believe in order that I might understand]. ${ }^{1}$ When I first studied this text many years ago, I thought I had Anselm trapped from the word go: if the argument was designed to stand alone, then how could it possibly demand belief as its premise? I now think that I judged Anselm superficially, since, so I will argue here, all interpretation demands faith of a kind. Interpretation is necessarily both allegorical and circular, and as we interpret, we all necessarily believe in order that we understand. The aims of the argument here are hardly more than descriptive; ${ }^{2}$ I have no exhortations to make to a profession that seems to me to be in, by and large, excellent hermeneutic health. When the argument does become critical of philosophical pragmatism, it relies on the insights of linguistic pragmatism to do so.

A short mid-twelfth-century text from the school of Saint Victor in Paris, the Allegoriae in Vetus Testamentum, interpreted Abraham's near sacrifice of Isaac in Genesis 22 in this way:

Journal of Medieval and Early Modern Studies 33:2, Spring 2003.

Copyright @ by Duke University Press / 2003 / \$2.00. 
Abraham signifies God the Father, and Isaac Christ. The mountain, on which he was to be sacrificed, expresses the height of the Lord's charity. The two young men waiting with the ass designate the gentiles and the infidel Jews consenting in the death of the Lord. The ass signifies the stupidity of both the gentiles and the infidel Jews. . . . Isaac, who did not suffer death in sacrifice, expresses the divinity, which did not feel the pain and grief in suffering, whereas the ram, who did suffer death, expresses the humanity of God, which did sustain the bitterness of suffering. ${ }^{3}$

I find this unpersuasive as an interpretation, largely because much in the text contradicts it. The interpretation leaves out of account the opening words of the biblical narrative, from which it's clear that Abraham is not God: "tentavit Deus Abraham" (Gen. 22:1). That opening defines the fulcrum of this story, which is about relations of obedience between humans (especially Abraham) and God. The exchange of the animal for human sacrifice seems to me the center of the story, and this exchange gains its full force only as long as we regard Abraham as a human, not as God.

If the twelfth-century interpretation is cognitively implausible, we can nevertheless see why it might have been attractive to a Christian reader and apologist. Texts from past cultures are at the same time precious and awkwardly at variance with the cultural order of the present; in this situation, interpreters habitually deploy allegory or its subset irony to accommodate texts from the past within new cultural imperatives. This is a fundamental resource of cultural recycling and renewal. In this case, we can see how the Old Testament passage is made relevant for Christians: the story suddenly becomes the story of its entire Christian readership. So far from being "their" story, this is "our" story. We've seen through Abraham, to Christ (i.e., "us") behind him.

Seeing the motive behind such a reading doesn't render it more persuasive. On the contrary, this cognitive failure points to a further inadequacy: the reading is, frankly, ethically obnoxious. This interpretation claims a Hebrew text for itself, and in the same move sets up a position from which to attack the Jews. The young men, passive, uncomplaining servants in the biblical narrative, are here transformed into the Jews willingly consenting to the death of Christ, while the poor ass becomes representative of their stupidity. The processes of what we might call cultural imperialism are pretty naked here: the "servant" culture provides the very material with which it will be condemned. 
This small example of biblical exegesis is representative, mutatis mutandis, not only of more than a millennium of biblical exegesis, but also of a very long tradition of neo-Platonic interpretation of classical poetry. ${ }^{4}$ As it is theorized in late antiquity, the processes of cultural imperialism were stated with revealing candor. Thus Jerome (d. 420), for example, offered an account of how Christian writers were to exploit classical pagan sources. Having dismissed pagan works as entirely empty, Jerome quietly shifts his position. Pagan works are, he says, like the captive women referred to in Deuteronomy 21:10-14. There we read that if an Israelite soldier should desire a woman captured in war, then he should bring her home to his house, where the woman will "shave her head, and pare her nails." After a month, the soldier may marry her. So too, argued Jerome, anything useful in the works of classical antiquity was to be "converted to our dogma," but "if we find anything superfluous ... we should cut it away, shave it bald, pare it with the sharpest razor in the manner of cutting nails." ${ }^{5}$

Jerome was, of course, discussing the use of classical pagan sources by Christian authors here, but his account of desiring and appropriating the spoils of cultural war describes equally well Christian exegesis of the Old Testament. Indeed, this very appropriation of the text of Deuteronomy is an example of that same process of claiming someone else's story to tell one's own. For all his attacks on the carnal reader, Jerome's own reading here is evidently what he would have called "cupidinous."

If the example from twelfth-century Paris is anything to go by (and it is), allegorization is understandable but pretty unattractive. It's both cognitively and ethically inadequate. The Christian exegete is radically cut off from knowledge of another culture by his act of appropriation: imbalances of power always distort knowledge, and it's the powerful who remain ignorant. They only know themselves, because they only see themselves. Ethically, too, we can see how this appropriation of the past to fit the uses of the present creates one readership only to exclude another. The Christian readership sees itself in the past. History points to them. The Jewish readership of this Hebrew text is, on the contrary, excluded from it. Power accrues to those who can "see through" the text, just as those who can't are disenfranchised.

Typological allegoresis never recovered from the drubbing it received in the Reformation by evangelical literalists; that distrust of allegory fed into a much wider Enlightenment distrust of any but the literal sense. Why, then, am I taking time to attack typological allegory again now? What has allegoresis to do with current interpretative practice? Surely this naive mode of interpretation is long since dead? Here I'd disagree; instead, it seems to 
me that the major currents of hermeneutics since the Enlightenment fit my description of allegorical interpretation pretty exactly.

The twelfth-century example works from an a priori conviction about the text's ground of meaning, and proceeds to relate what is to be interpreted back to that ground. Christ is the prior ground that generates meaning, even if the fiction of the interpretation is that Christ stands posterior to the text. The notion of Christ evidently generates and preempts the interpretation. All interpretative traditions, whether they recognize it or not, do this: they all posit an opaque ground of meaning that is apparently illumined by the work, but that in reality illumines the work. For the ground of meaning evidently stands a priori to interpretation of the work. The interpretation has it that the work is about the ground of meaning, implying that the ground of meaning cannot itself be "about" anything: Abraham is "about" God, but God cannot be about anything. He just is. If an interpretation arrives at God, then we should be satisfied. We must, indeed, be satisfied, since by definition God cannot be understood. The point of arrival in this interpretation is also the point of departure, making a circular journey; the strongest evidence that the passage points to Christ is the assumption that it will. That the ground of meaning is the point of departure is a statistical certainty, given the unfailing regularity with which typological interpretations arrive at the same meaning.

Occasionally a hermeneutic tradition is quite explicit about the a priori, prejudicial status of the meanings at which interpretation must arrive. A tradition that gives priority to an interpretative community over the texts it interprets will not be embarrassed about such a frank admission. Thus Augustine (d. 430) defines a rule in the De doctrina christiana for distinguishing figural from literal meanings:

A rule of this kind will serve in the treatment of figurative expressions, that what is read should be considered with a diligent scrutiny until an interpretation contributing to the reign of charity is produced. If this result appears literally in the text, the expression under consideration is not figurative. ${ }^{6}$

The prejudice in favor of a predetermined reading here is so strong that it even determines the rhetorical level of the text itself; if the text contributes to the reign of charity, then it is by definition literal. If not, then it is figurative and must be worked on until the predetermined ground of meaning has been arrived at. 
Talk of opaque grounds of meaning in biblical hermeneutics designedly points to metaphysics. When we consider the grander hermeneutic movements more familiar to our own practice (even those that disavow metaphysics), we can see that each of these, too, has its own metaphysical ground of meaning. To arrive at this ground completes a satisfactory intellectual act, since, as the ground of meaning, it disallows further investigation. Each tradition posits a ground of meaning as an act of faith, and then goes about interpreting the text as an epiphenomenon of that ground of meaning. The surface features of the text are symptoms of the ground, evidence to be "seen through." For Hegel, the ground was the World Spirit working through History; for Marxists, it was the Class Struggle; for neo-Kantians like Croce and the New Critics, the ground was Art; for Foucauldians it was Power; for Freudians the Unconscious; and for Deconstruction it's Textuality. Each of these movements produces its own allegorizing, since for each the text "says one thing but means another." The surface level of the text should, according to each of these positions, be "seen through" to a deeper, latent ground below it. Each position performs a hermeneutic equation according to the formula "x seems to be about $y$, but in reality it's about z." Consider Paul de Man on Proust, for example:

Everything [in Proust's novel] signifies something other than what it represents . . . it is always something else that is intended. It can be shown that the most adequate term to designate this "something else" is Reading. But one must at the same time "understand" that this word bars access, once and forever, to a meaning. 7

Anything at the literal level of the text that resists being seen through turns out to be an example of the ease with which appearance can disguise reality. But reality is immutable and will have its way; the adverbs in de Man's comments suggest no escape: "always," "once and forever." One "must" understand reality.

Each hermeneutic camp has a name for anyone who would resist the perception of "reality." The "carnal litteralist," or, indeed the Jew, who refuses to see Christ in the Old Testament, has his or her counterpart in most hermeneutic traditions: victim of bourgeois ideology; repressed victim of the superego; philistine; humanist; logocentrist. And finally, each of these traditions develops little fictions that dramatize the struggle to read properly, and each promises the millennium to those heroes who succeed. This is evi- 
dently true of Christianity and Marxism, but it's also true of, say, Deconstruction. In The Ethics of Reading, for example, Hillis Miller provides a classic account both of the reader-hero's drama, and of the millennium toward which he or she moves:

It is impossible to get outside the limits of language by means of language. ... To live is to read, or rather to commit again and again the failure to read which is the human lot. We are hard at work trying to fulfill the impossible task of reading from the moment we are born to the moment we die. We struggle to read from the moment we wake in the morning until the moment we fall asleep at night, and what are our dreams but more lessons in the pain of the impossibility of reading? ${ }^{3}$

Thus the fiction of rigorous struggle in this Protestant version of Deconstruction, and herewith its promise:

I would even dare to promise that the millennium would come if all men and women became good readers in de Man's sense, though that promise is exceedingly unlikely to have a chance to be tested in practice. ${ }^{9}$

I might seem to have arrived at a rather depressing point. Hermeneutic traditions, both medieval and modern, appear, that is, to be relentlessly preemptive, buying up the discursive space before the interpretative transaction takes place. In that case, the interpretation is a kind of charade, since we know who is going to end up with all the discursive property in advance. All conform to the pattern of cultural appropriation promoted by Jerome, where the Egyptian women are captured and shaven to suit the desires of their captors. And all these traditions would appear to subject the text by seeing through it: just as the police interrogator "sees through" his victim to a meaning he knows will be arrived at, so too do hermeneutic practices of this kind see through their victims. No text is innocent. Readers know what texts are hiding, and they'll have it out before they're finished. The only serious intention to be overcome is the victim's intention to hide the truth.

Seeing through the text in this way is both cognitively and ethically inadequate: cognitively, it consigns us to the ignorance of the powerful; and ethically it is comparable to all the objectionable practices I've just used as 
metaphors: monopolistic trading; appropriating military spoils; the interrogation techniques of the police state.

Is there, however, any alternative, or is this simply the way interpretation works?

The obvious solution is an appeal to interpretative traditions that scrupulously abjure any attempt to "see through" texts to a hidden meaning. Positivism and its reliance on the literal sense beckon powerfully. A positivist approach has it that the entire meaning of a text is contained in its words, and that we should restrict ourselves to that meaning, to the words on the page.

This tradition will surface within particular historical environments. A body of readers (e.g., evangelical readers in the sixteenth century) may feel hoodwinked by the mystifications of "expert" allegorization, and so promote the literal sense as the only sense. Or an avowedly subservient institution might feel scrupulously bound to avoid searching for hidden meanings in the texts it receives from a higher authority. The English judiciary exemplifies this last case. English judges are expected to execute the laws made by a sovereign parliament; this division of power extends, as it must, to matters of interpretation, since judges do not legislate, but rather enforce legislation. Acutely aware of the invasive tendencies of intuitive interpretation (especially intentionalism), this is what Lord Reid said in 1975 about the textual prerogatives of judges:

We often say that we are looking for the intention of Parliament, but that is not quite accurate. We are seeking the meaning of the words which Parliament used. We are seeking not what Parliament meant but the true meaning of what they said. ${ }^{10}$

According to this tradition, as E. D. Hirsch has argued, the Pauline dictum is reversed: "the spirit killeth, but the letter giveth life." I

Positivism might seem to avoid the ethical objections that apply to preemptive allegoresis. It also seems to avoid the strongest rational objection to allegory, which is that such interpretation is circular. The meaning arrived at when we allegorize is, as we have seen, the one that generated the interpretative process in the first place. Or, to put it slightly less baldly, we generate our understanding of the meaning of a text on the basis of evidence whose meaning we have already inferred from that very text. Positivism promises to break out of that circularity.

In what remains of this section, I offer a brief, rhetorically graded 
series of examples designed to demonstrate that positivism, for all its apparent attractions, is not remotely sustainable. The immediate point of these examples is that the words on the page do not offer up their meaning. A further point that will emerge is that plausible accounts of meaning are necessarily circular.

Allegory flourishes in cultural environments where the phenomenal world is taken to be a sign of higher powers at work. Given the prestige of allegory within religious cultures, it is unsurprising that religious writers should have built allegories into their own fictions. I was once very puzzled by lines 48 to 55 of the Old English poem The Seafarer (ca. 10th cent.). These lines describe an apparently idyllic spring scene, which, the narrator says, provokes him to leave the world. Why should an idyllic spring precipitate such rejection? The answer to this apparent contradiction lay in a biblical passage (Luke 21:29), in which Christ likens the signs of coming spring to the signs of the end of the world. ${ }^{12}$ The "words on the page" are themselves nearly silent about their "real" meaning, and offer insufficient evidence for that meaning; we need to refer outside those words, to the textual dialogue in which The Seafarer is participating. The premise of our looking outside the text is that its meaning is unavailable within its words, that the text "says one thing but means another." Without adducing that allegorical motor of meaning, by sticking to the "words on the page," the text remains incoherent.

My second example against positivism is irony. In classical and medieval rhetoric, irony is a subset of allegory: allegory "says one thing and means another"; irony "says one thing and means its opposite." When we look to irony, we see the same necessity to refer to an originating intention outside the text. Swift's Modest Proposal (1729) argues that Irish babies be sold as food, thus solving the problems of both famine and overpopulation in a single move. Swift's "words on the page" will certainly make us acutely uneasy, but in themselves, taken literally, they mean only what they say. The peculiar mixture of social delicacy, rational argument, and blind viciousness in the Proposal creates unbearable strains for a reader committed to a positivist reading. As soon, of course, as we admit an unspoken, ironic strategy, that strain is transformed into relief of sorts. With what justification do we assert that the author "means the opposite" of what he says? We can only do so by first positing, then testing the force of, an informing yet unstated meaning. Once we see how effective that strategy would be, we tend to accept it. It's our identification of the unstated meaning generating the text that transforms what the words mean into what the author means by them. The 
bizarre locutionary force of the words (what they say literally) is transformed into a believable strategy by perception of their illocutionary force (what we take the author to intend by them). ${ }^{13}$

We actively participate in the construction of meaning by trying to identify the strategy behind words. Even if we identify that strategy wholly from within the text, with no reference outside it, we still, conceptually at least, posit that strategy, or intention, as logically prior to, and therefore outside the text. We are obliged to enter (not to break out of) an apparently vicious circle when we interpret. We are obliged, that is, to lead back to intentions on the basis of meanings that have been accounted for by those very intentions.

Lord Reid's solution of looking simply to the meaning of the words on the page vastly impoverishes our understanding. Within his terms we cannot move from what the words of a text mean to what an author meant by them. Positivism is hopelessly equipped to cope with linguistic situations where complete clarity isn't possible. Parliament, by definition, speaks from a position of power, and assumes itself able to avoid linguistic obliquity in its legislative dicta. Authors of many kinds, on the contrary, are often obliged or predisposed to adopt linguistic subterfuges. Positivism is, indeed, massively underequipped to meet the complexities of social existence more generally, since we necessarily inhabit a world in which expressions do not say what they mean. All human forms of communication, in whatever discursive field, say one thing and mean something else. For the most part we are able to forget this, participating in systems of communication that are shored up by deeply ingrained conventional habits of unspoken agreement. Textual interpreters of literary, legal, and biblical texts, whose meanings are subject to powerful competitive forces claiming different meanings, are unable to forget the fragility of the literal sense.

I'm moving down the rhetorical ladder, from larger scale figures of thought to smaller (allegory to irony). I now turn to a local figure of thought, metaphor, since here, too, we necessarily infer unstated meaning. Take Donne's "No Man is an Iland, intire of itselfe." 14 Taken literally, this statement is true but uninformative: no man, is, indeed, an island. The simple point of the statement is only perceived if we recognize the word island as a metaphor. And this simple recognition is only possible if we allow ourselves to infer an unspoken meaning. We do this on an ethical impulse, since we simply assume that Donne (d. 1631) must mean more than he says; he wouldn't waste our time with uninformative statements, and he wouldn't discuss islands in a meditation. Our reading of the metaphor proves Donne's 
point: that no man is, indeed, an island. We assume that Donne's statement has what the philosopher and protopragmatist Grice called "implicature," which is to say, logically unmotivated implications. ${ }^{15}$

"Implicature," which in good part generated the branch of linguistics known as Pragmatism, points to that area of meaning beyond the reach of semantics. "Where's Bill?" someone might ask, to which the response might be "There's a yellow VW outside Sue's house." 16 The semantic content of the reply offers no response to the question; on the face of it, and by a positivist reading, the response is irrelevant to the question. We make these two statements a part of a single narrative, however, on the assumption that the respondent is in fact answering the question. The appearance of irrelevance merely provokes us to hypothesize relevance at a further level. We infer many things, in fact: that the respondent is sane; that the answer is relevant; that the car had transported Bill, and that Bill is at Sue's house. None of these inferences is logically generated; they are, on the contrary, inferred simply from an expectation of conversational relevance.

Relevance is one of Grice's four principal maxims of conversation, all of which are contained under a general principle of cooperation. The other three are quality (do not lie), quantity (offer only as much information as the exchange requires), and manner (avoid obscurity or ambiguity, and preserve a chronological order of narration). Readers familiar with medieval poetic treatises will be amused at these maxims, since those treatises encouraged writers to break almost each one of them. Grice, however, absorbs literary language by showing how flouting the maxims continues to produce inferred meaning. These inferences are testimony to the "remarkable robustness of the assumption of cooperation: if someone drastically and dramatically deviates from maxim-type behaviour, then his utterances are still read as underlyingly co-operative if this is at all possible," 17 Donne's "no man is an island" flouts the maxim of relevance to observe with especial force the maxim of quantity, offering a great deal of information in a very short space.

It might be objected that the examples I've chosen are rather special cases, and that a good deal of language is fairly clear, unambiguous, and self-sufficient. I don't think this is true at all. Grice generated his theory of "implicature" out of the practice of conversation; he reveals that any conversational exchange relies on a complex and dense exchange of implicatures surrounding the semantic content of the conversation. Consider the way Levison unpacks this simple exchange: 


\begin{abstract}
A: Can you tell me the time?
B: Well, the milkman has come.
\end{abstract}

It is only on the basis of assuming the relevance of B's response that we can understand it as providing a partial answer to A's question. The inference seems to work roughly like this: assume B's utterance is relevant; if it's relevant then given that A asked the question, B should be providing the answer; the only way one can reconcile the assumption that B is co-operatively answering A's question with the content of B's utterance is to assume that B is not in a position to provide the full information, but thinks the milkman's coming might provide A with the means of deriving a partial answer. ... If the implicatures were not constructed on the basis of the assumption of relevance, many adjacent utterances in conversation would appear quite unconnected. ${ }^{18}$

Luckily we do not need to explicate the inferences we habitually and rapidly make. An example such as this, however, challenges any easy separation of literary and ordinary language on the grounds of complexity. ${ }^{19}$ How, all these examples demand of us, do we get from what a statement means to what a speaker or writer means by it? Without a notion of unstated meaning to appeal to, all verbal signs remain forever cut off, floating helplessly as disiuncta membra in a world of perpetual unreadability. The words on the page or in conversation do not state their meaning, and we need to enter a circle, be it vicious or virtuous, before we can interpret. Within any text (however one understands that term) we need to interpret the part by the whole, and the whole by the part, and we account for meanings of both parts and whole on the basis of evidence whose meanings we have already inferred from both parts and whole. Positivism may be a necessary fiction in certain discursive situations (e.g., the law), but it does not correspond to the way we habitually read and interpret.

The promises of philology, from language acquisition to lexicography, grammar, rhetoric, codicology, and textual criticism, derive historically from an unbridled, sixteenth-century confidence in the literal sense, itself a reaction against a pragmatist reception of the Bible. ${ }^{20}$ The actual production of meaning turns out to be a much more complex affair, in which the resources of philology, while significant, have only a limited reach.

I am arguing, then, that pragmatism in the sense used by linguists is unavoidable. Philological analysis of meaning takes us only so far, a long way but never far enough; a pragmatic approach becomes rapidly necessary 
in any interpretative act. And a pragmatic approach is circular. Cognition of meaning is in good part recognition, supplying familiar meanings that make sense of what we try to decipher. ${ }^{21}$

A final example confirms these points; it also reminds us that the texts we try to interpret have already undergone a process of precisely this kind of interpretation before most readers even begin to interpret. The three earliest complete witnesses to Henryson's Fables (ca. 1470) present this reading $(\mathrm{A})$ at lines $15-16$ :

The nuttis schell, thocht [although] it be hard and teuch [tough],

Haldis the kirnell, and is delectabill.

Two other witnesses present, by contrast, this reading (B):

The nuttis schell, thocht it be hard and teuch

Haldis the kernill, sueit [sweet] and delectabill.22

In $\mathrm{A}$ the shell is delectable, in B the kernel. Which reading does an editor choose? Grammar provides no help, since both are grammatical. Sense would seem to offer the solution, since A is, apparently, nonsense: the nut's shell is simply not "delectabill"; we know that anyway, and the first line has said as much.

The matter is not, however, so simple. Henryson is working within the interpretative tradition of the nut and kernel, whereby the nut corresponds to the outer surface of the story and the kernel the fruitful meaning. For the moralist, who seeks abstract meanings in fiction, the shell is tough and the kernel sweet. For the lover of narrative, however, it's the other way around. This metaphorical correspondence of shell/narrative and kernel/ meaning is therefore complicated, since its point is paradoxical: on the face of it, the outer surface of the story is the delectable bit, and the abstract meaning tough. That's the way it seems to a lover of fiction who reads for the story. The moralist, however, insists on the reverse: the shell/narrative is tough and the $\mathrm{kernel} /$ meaning sweet. A defender of the reading in A could point to prior examples of the shell being described as sweet.

At this point the question of choice is posed again. An editor might try to make a decision on codicological grounds; in this case the codicology offers a marginal support for $\mathrm{B}$, as the majority reading among reliable witnesses. There is also a line in one of Henryson's Latin sources that would support B. All that said, one could object that Henryson is a sophisticated poet concerned to shake readers out of any confident sense of where meaning is 
located. This is precisely what he goes on to do in the first fable of the collection. The choice between A and B can be made, finally, according to a sense of what kind of poet Henryson was, and this can be ascertained only by testing many other loci in which an identical lack of certainty may pertain.

Editors and interpreters are, then, faced with identical problems. ${ }^{23}$ Editors must have a sense of what kind of author they are dealing with before they can begin editing. Thus Kane and Donaldson, as editors of Piers Plowman, at first rigorously eschewed biography in the belief that they had to establish the text without prior assumptions about authorship. Donaldson later declared that he couldn't construct the texts without such assumptions. ${ }^{24}$ The practice of the Athlone edition of Piers Plowman is correspondingly circular. Kane and Donaldson constructed their text on the basis of understandings about Langland's habitual practices as a poet (one who prefers, for example, density to simplicity of expression). ${ }^{25}$ Needless to say, their understanding of Langland's practice as a poet was derived from the text that the editors had to construct.

Editorial theories that would minimize the input of an editor by constructing stemmata are, it should be remembered, themselves fundamentally circular. Stemmatics, that is, is designed to discriminate "authentic" from "spurious" readings by the construction of genealogies of shared error; stemmatic method can only begin, however, by isolating error in the first place. The method designed to isolate error can only begin by positing error. Editors often take each other to task for begging the question, or petitio principii; in my view this is in itself a weak attack, since all editorial theory and practice depends on circular reasoning. The circle might be bigger or smaller, requiring more or less faith, but circularity itself inevitably characterizes editorial theory and practice.

Perhaps my description of editorial theory and practice seems geared to the production of a text designed to elucidate authorial intention. Some editorial theory abjures the attempt to isolate authorial intention; it is instead designed to understand how a text is institutionally produced or transmitted by scribes through time. ${ }^{26}$ Such an editorial theory and practice will, however, face identical problems. Such a practice will, that is, find itself intuiting the strategies of nonauthorial individuals or groups involved in the production of texts. Denial of authorial intention only briefly defers the moment at which the need to infer intentions will resurface. Hermeneutics is like a hydraulic system: depress one source of meaning in one place, and it soon resurfaces in another.

In conclusion to this repudiation of positivism, then, we can say 
that all texts are finally susceptible to the following descriptions. They do not, and cannot state their full meaning, even if we were to limit "meaning" to "meaning intended by the author." Hypotheses about that unstated meaning are necessarily derived from circular reasoning. Accounts of the meaning of texts are supposed to explain the features of a text; those features are at the same time the primary evidence on which we hypothesize meaning in the first place. Texts, then, are all allegorical; they all "say one thing but mean another," even if there are differing distances between what they say and what they mean. Meaning derives, in the succinct twelfthcentury account of allegory, "rather from the sense from which the words derive than from the sense that the words make" [potius sensum ex quo fiunt verba quam sensum quem faciunt verba]. ${ }^{27}$ And, in circular fashion, our primary evidence for the sense from which the words derive is the sense made by the words.

In order to move from locutionary to illocutionary meanings, we assume an author or presence of a kind behind texts, acting in certain ways. This is obviously true for critics like myself who unashamedly interpret with the primary (not sole) aim of understanding authorial strategy. It is also true, if less often recognized, of critics who dismiss authorial intention and prefer to work instead within interpretative frameworks generated by hypostases such as, say, Power or Textuality. The antihumanist hermeneutic schools of the twentieth century repudiated authorial intentionalism, having lost faith in individual persons as sources of meaning. In fact, however, these movements themselves deployed the notion of a person's intentions in their account of meaning. For they could not help but personify their chosen ground of meaning as an author who intends the meaning arrived at.

Deconstruction, for example, often drew on the Heiddegerian dictum that it is not Man who speaks language, but Language who speaks man. These grand claimants to hermeneutic power are themselves intentionalist, that is, in identifying meaning and authorship. The only difference, and it's a very small one, is that the author is no longer a human, but (say) History, Power, or Language, each of which is invested with its own interests and purposive motive. Any account of history that attempts to isolate the driving power of a system beyond individual agency tends to personify that system. And once the system is personified, we necessarily talk about its operations by appealing to the notion of personhood.

If the reasoning upon which we base interpretation is circular, such reasoning is at some level a matter of faith. Words simply cannot serve as the guarantor for their meanings. We assume, as an act of faith, certain 
things about writers and about communicative exchange when we interpret. These assumptions are nonlinguistic. They can instead be fairly described as ethical assumptions, since they concern matters of communicative cooperation, to use Grice's term. ${ }^{28}$ The only way we can break into an interpretative circle is ultimately by a leap of ethical faith: rationally perceived probabilities may take us very close to meaning, but we can only generate meaning by making a leap into the strictly unknowable.

Faith is most obviously and unashamedly operative in explicitly theological traditions. It is also operative in psychoanalytic traditions: if all attempts to resist a psychoanalytic interpretation are themselves interpreted as resistances to the psychoanalytic truth, then no persuasive counterinterpretation can be imagined. Denying the possibility of a counterinterpretation implies a very powerful exercise of faith. We might respond by describing psychoanalysis as a kind of theology, but it will be obvious that I think the distance between theological thinking and all other hermeneutic traditions is much shorter than is normally thought: all interpretation, that is, demands faith of a kind in the matter of understanding. The difference between one tradition and another does not lie in the absence or presence of faith; it lies rather in where we choose to locate our faith. "Truth," its etymology of troth might remind us, is inseparable from ethical commitments.

Hermeneutics, as is commonly agreed, derives etymologically from Hermes, the messenger of the gods. While hermeneutics will always be central to revealed religions in particular, my argument here is that all interpretation demands, like religion, the exercise of faith. This faith is religious in the probable etymological sense of religion ("binding," from religare). It is not at all, however, necessarily religious in the formal sense. It might, for example, be the faith implied by Cicero (d. 43 B.c.) in his discussion of how different communal practices necessarily involve faith, beyond written law. In the De inventione, for example, Cicero shows how an advocate might argue in favor of reading a will according to the intention of its author, and against what the actual words say. This advocate should mount a full-scale defense of what we would now call linguistic pragmatism; he should argue that

all cases are not covered by exceptions expressed in writing, but some that are self-evident are covered by exceptions understood but not expressed. Then it may be urged that nothing at all could be done either with laws or with any instrument in writing, or even about our every day conversation and the orders issued in 
our own homes, if everyone wished to consider only the literal meaning of the words and not to follow the intentions of the speaker. ${ }^{29}$

The conclusion of this position is that "we value the laws not because of the words, which are but faint and feeble indications of intention (tenues et obscurae notae ... voluntatis), but because of the advantage of the principles which they embody." 30

III

Positivism had seemed to offer a momentary escape from the circular, preemptive, appropriative predations of allegory. In fact, however, Derrida and de Man are right in this respect: all language is susceptible of rhetorical opacity, and an allegorical, aporetic relationship necessarily pertains between signifier and signified. ${ }^{31}$ This relationship is not logically motivated, and can never therefore be logically proven, however much the tools of philology can vastly narrow the possibilities. Allegorizing, as we have seen, bridges that aporia.

Linguistic pragmatism as defined above clearly places considerable power and responsibility in the hands of the interpreter. Does an acceptance of linguistic pragmatism necessarily involve acceptance of philosophical pragmatism? Stanley Fish, for example, presents a powerful extension of linguistic pragmatism into hermeneutics more generally. For Fish the interpretative community does not merely participate in the construction of meaning; it constructs the meaning from the bottom up, according to the protocols of that interpretative community. Texts, their meanings, and their authors' intentions are, in Fish's view, only as interpretative communities decide them to be.

Clearly there's much in my argument thus far that would lead me precisely to the position defined so forcefully by Fish, insofar as both his position and mine recognize the decisive role played by interpreters in the construction of meaning. There are, however, obvious and worrying implications in Fish's position. In the first place, it would seem to disallow us ever learning anything about the past, since it places all the initiative in the hands of the intepretative community: the interests, in all senses, of that community drive the lines of interpretative enquiry and choices. The past is wholly constructed by the interests of the present, and there is, strictly, no historical object that exists prior to its being constructed by an interpretative commu- 
nity. Interpretation would in that case serve simply to reaffirm the agreed prejudices of interpreters.

The other worrying implication is that we become unable ethically to distinguish one interpretative community from another. European history provides many examples of textual communities that have decided on brutal versions of what is reasonable, and which have remade the records, in exactly the way Fish argues is inevitable, to suit that interpretation. Philosophical pragmatism has been hailed by liberals, but it has an uneasy proximity with authoritarian interpretative practice. ${ }^{32}$ In all examples of allegoresis discussed above, for example, the inevitable gap between words and meaning is filled in a preemptive way; all the discursive space has been bought up by the exegete before the ostensible interpretative transaction takes place. The local contours of the text have been "seen through"; they are merely symptoms of a larger metaphysical category.

There may be no alternative to allegoresis, but is there an alternative to allegoresis in its most appropriative, culturally imperialistic forms?

An appeal to the intention of an author or text might promise the solution, since intention locates meaning in the text, and an appeal to intention might seem to minimize the powers of the interpretative community. Antipragmatists have traditionally taken this line; Lollard and sixteenth-century evangelical exegetical theorists, for example, did precisely this against their pragmatist opponents. ${ }^{33}$ This is an ethically attractive possibility, since the perception of intention is, in legal practice at any rate, intrinsic to the exercise of justice: what the defendant "did" is often largely a matter of what the defendant intended. That intention is taken to inhere in the defendant's act; it is not taken to be constructed by the interpretative community.

Intentionalism was such a contested concept in twentieth-century literary criticism for different reasons: either it was dismissed because literary critics sought to define an idealist status for literary discourse impervious to the scrutiny applicable to all other forms of discourse (New Criticism); or because its reasoning was circular (the intentionalist fallacy); or because antihumanists believed that authorial intentions were no longer a significant source of meaning (e.g., Foucault). From the previous section it will be clear that I am unpersuaded by any of these three objections to intentionalism. With regard to the idealist tradition, I reply that works of art are not selfenclosed, sui generis objects whose linguistic status is indefinable by all the ways we define other kinds of textuality. To the second charge of circularity, one could reply by saying that intentionalism is not weak simply because 
it is circular; all interpretative reasoning is circular. And to the third charge, that of the antihumanists, one might point out that antihumanists themselves attribute intention to the hypostases in which they repose the true motor of meaning. Such critics also, it should be added, attribute intention to human authors: in order to read "against the grain," the grain has to be located. ${ }^{34}$ All my examples have simply assumed that we interpret by locating authorial intention (however we define author, either as human agent or personified hypostasis).

In itself, however, intentionalism offers no escape from allegory in its most predatory form. For intentionalism is itself an allegorical method. Its very premise is that the text "says one thing, but means another." Intentionalist interpretation is generated, that is, precisely out of the fact that the words on the page do not in themselves provide us with satisfactory meanings. Correlatively, allegorical exegesis itself tends to be unashamedly intentionalist: the twelfth-century interpreter with whom I began had no doubt that the biblical narrative was written by God, and that God intended those meanings. Intention, as Rita Copeland has said, is "the most flexible and expedient of rhetorical concepts, adaptable and attributable in any circumstances." 35

Might faith make a difference? One could dispose of faith as itself a construct of the interpretative community in exactly the way I have just done for intention. Rather than taking that route, I want to argue that Fish's position is vulnerable once considered as an exercise of faith.

Fish, as we have seen, argues that everything about a text, its very making in some profound sense, is constructed by the interpretative community. He repudiates all attempts to locate something outside, prior to and constraining the operations of that community. His position allows no countercases to the rule that "interpreters are constrained by their tacit awareness of what is possible and not possible to do, what is and is not a reasonable thing to say, and what will and will not be heard as evidence in a given enterprise." 36 Interpreters can be constrained only by these considerations, and not by anything outside or prior to the act of interpreting, whether that be the author's intention, or the formal properties of the text, or anything else. The omnipotence of the interpretative community here is clearly itself an act of faith, since it can admit no countercase.

In my view Fish's position has missed something crucial about its own construction. Radical philosophical pragmatism, in mounting the case that texts are wholly made by a given community, necessarily employs arguments about what texts really mean prior to being interpreted by that com- 
munity. One of the standard ways in which the argument for interpretative relativity is made is by reference to the way in which interpretative paradigms shift across time. Thus, to take one of Fish's examples, sociological, semiotic, and anthropological interpretations of detective fiction have been put forward. The success or failure of any such approaches "prove[s] nothing about what the text does or does not allow; it would only attest to the degree to which I had mastered or failed to master the rules of argument and evidence as they are understood (tacitly, to be sure) by members of the professional community." 37 This argument declares that the detective novel only exists in our interpretation of it, and that this perception can be extended to all texts - they are as we make them. This argument necessarily employs, however, claims really to have understood texts (i.e., the sociological, semiotic, and anthropological interpretations). Fish's arguments about being locked into the present are frequently premissed on claims really to have understood texts produced by different interpretative communities. He refers confidently, that is, to his opponents' theories and to exegetical theory of the distant past, such as that of Augustine. ${ }^{38}$ These confident claims are marshalled in support of the argument that we make texts. Fish cannot, that is, mount the argument that we wholly construct texts without claiming historical knowledge of other theorists from different interpretative communities. The very conduct of the argument belies its claim. ${ }^{39}$

Fish could, of course, reply that his accounts of Augustine's meaning are themselves constructions. Yes, but if that's true, then all his arguments and their supports, and their supports, ad infinitum, fall under the same description. That is one response, but it leaves the theory that we construct everything looking like the merest truism: in some very weak sense, we construct the meaning of texts. No one else does it for us. That is true but uninformative, applying as it does to every text we read.

If a critic in Fish's position wished to preserve a stronger version of the case, it might be conceded that the confident claims about what texts really mean apply only to exegetical texts. The objects of enquiry (the literary texts, however that category is framed) are, so the defense might run, themselves wholly constructed. That reply relies, however, on a radical and idealizing distinction between literary and exegetical discourse: one (the exegetical) implicitly exists prior to the intepretative act, while the other (the literary) does not. Many scholars will want to preserve some distinction between exegetical and literary discourse. ${ }^{40}$ Such a distinction, however, does not necessarily involve saying that one (the exegetical) exists prior to our interpretations of it, while the other (the literary) exists only as we inter- 
pret it. If we can make believable hypotheses about what exegetes from the past really meant, then why can't we do the same for what authors of the Urtexts really meant?

That interpretations change, moreover, is not itself irrefragable evidence that they are wholly constructed. The fact that we regularly change the discourse we use to broach experience (especially disease and the ravages of war) implies precisely the reverse: that is, that the phenomenon has a very real existence prior to and beyond our discursive constructions of it. And neither does the fact that intepretations differ according to discursive position necessarily imply that the interpreted object is wholly constructed in any profound sense. If a physicist, a furniture historian, and an anthropologist all study a piece of furniture, they will come up with entirely different results. That doesn't mean that what their results point to isn't "really there," or that the object has no existence outside and beyond those discursive projections. On the contrary, the very fact that no one kind of interpretation can embrace the whole object implies the resistance of the object to interpretations to which it may be subject.

It might be the case, then, that there is at the heart of Fish's position an untenable distinction between different kinds of texts, one constructed by the interpretative community and the other not. I suggest that this distinction points to the inescapability of faithful interpretations that posit texts as existing prior to the constructions placed on them by interpreters. We don't believe that we simply construct history.

Radical pragmatism has a problem with texts from the past, then. It must exercise faith in some texts as truly existing prior to interpretation in order to mount a case that others don't. It may also be the case that radical pragmatism has a problem with the present. Philosophical pragmatists posit that we are definitively locked into present constructions, and they encourage us to recognize those constructions as themselves just that - not accounts of the world as it is, but of how we have been trained to make it. Within these pragmatic communities, Fish and Rorty lay great emphasis on the solidarity of pragmatists; Rorty in particular often uses the phrase "we pragmatists." This is unsurprising from a position that stresses the overwhelming significance of the interpretative group's importance; the very use of the word community is itself designed subliminally to imply solidarity.

If we are locked into our discursive positions, without any world prior to or beyond them to which we can appeal, then relations between interpretative communities will inevitably be bad. Rorty confronts this with admirable candor, saying that the only thing one interpretative community 
can do to another with which it disagrees is to make it "look bad." 41 How that squares with his main ethical point that humiliation is the worst thing of which humans are capable I leave to others to consider. What interests me here, rather, is the kind of solidarity that can pertain between members of a radically pragmatist community. The radically pragmatist interpretative community constructs the world, without believing that there is any real world out there beyond those constructions. Presumably, then, individuals do the same: they construct the world without belief in the alterity of others. This seems to me to be a solipsistic account of how individuals operate in the world, and an account that has no place for faithful belief in the existence of others prior to our constructions of them. It seems, in short, an exiguous if not impossible basis for a community.

This observation applies, moreover, to our membership of communities of the living and the dead. Philosophical pragmatism privileges the community of the present without ever acknowledging that interpretative communities might have a longue-durée. It certainly is the case that individuals interpret the world according to received criteria. Those criteria are not, however, necessarily bound to, or produced by, the present. There is nothing inherently coherent about the present, and nothing inherently divided between the present and the past. One source of our faith in historical knowledge might be that individuals in the past thought, in crucial respects, as we think now. Indeed, it is plausibly the case that we think now as we do precisely because they thought then as they did.

At the very least, we can say that the hermeneutic version of radical pragmatism presents a paradox: it highlights community values as the only locus of interpretative authority, while withdrawing faith as the fundamental ground of community formation.

Faith, then, might make a difference to what we believe we are doing. Might it make a difference to what we do? I argued above that the essential difference between one interpretative tradition and another is not the presence or absence of faith; it is instead the entity or entities in which a tradition reposes its faith. One tradition cannot claim superiority over another by virtue of its indisputable certainties or lack of reliance on circular reasoning. Interpretation does not provide indisputable certainty, and it necessarily uses circular reasoning. So interpretative practice is a matter of choice: choose the source (or sources) of your faith/s, and your texts will offer up meanings accordingly.

So fundamentally, no, faith does not make a difference to what we do. What does make a difference is the entity in which faith is reposed. The 
history of legal interpretation offers many sobering examples of interpretative violence that issued in physical violence (the persecution of "witches" by trial in the sixteenth and seventeenth centuries is an apt example). History also offers many spectacular examples of enduring interpretative aggression (e.g., typological allegory). The language of interpretation is itself heavily influenced by the language of the law (e.g., critic, from крtтns, "a judge"; author; sentence, in the medieval sense of sententia; witness; evidence; thesis; hypothesis). ${ }^{42}$ Such language, however, both as a description of normative and improper hermeneutic practice, often evokes the way in which a corrupt law tortures or abuses the defendant ("interrogating" the text; "twisting" the evidence). 43

When it comes to consider how one might make choices about the sources of one's faith, it may be worth bearing in mind this violence, and to note that the greater the level of faith required, the more likely the level of violence. Certainly within the realm of interpretation itself, those traditions that demand very high levels of faith produce the interpretations that, in retrospect, look the most invasive and appropriative. Such traditions (e.g., typological allegory) are the ones in which all interpretations end up at the same answer; to arrive at that level of identity necessarily requires a very aggressive stripping away of the literal sense to perceive the distant ground that produces it. ${ }^{44}$ In retrospect, these are the interrogational practices that tend to strike an author dead by conducting a "great reckoning in a little room."

The sobering history of interpretation provokes me to beware of hermeneutic aggression that suppresses the alterity of its subjects. I choose to adopt a more friendly hermeneutics, based on faith in persons as ethical agents. Certainly history cannot be recounted without recourse to personification of the systems that determine and are determined by purposive human action. Those systems cannot, however, tell the whole story. Once we do tell the whole story from the perspective of those forces, we tend to exercise an invasive hermeneutics of suspicion. A more friendly hermeneutics, based on faith in persons as ethical agents, does not do away with suspicion (we often suspect persons). It does, however, produce interpretations that respect the alterity of its subjects, and it does produce interpretations that are contestable. It also relocates textual and cultural interpretation from the realm of theory to that of hypo-, or under-theory. 


\section{Notes}

Many friends read a much earlier draft of this essay. Few agreed with all its conclusions, but all were exceptionally generous in their constructive criticism. I thank in particular David Aers, Chris Cordner, Jeremy Dimmick, and Paul Strohm.

1 St. Anselm's "Proslogion," with "A reply on behalf of the fool" by Gaunilo, ed. and trans. M. J. Charlesworth (Oxford: Clarendon Press, 1965), 114.

2 That interpretation is necessarily a circular process is an old point, first stated as such by Friedrich Schleiermacher (1768-1834); see, for example, Schleiermacher, Hermeneutics and Criticism and Other Writings, trans. and ed. Andrew Bowic, Cambridge Texts in the History of Philosophy (Cambridge: Cambridge University Press, 1998), $109,231-32$. Very little in the history of interpretation is genuinely new; the point bears restatement. The line of my argument is consistent with, though differently angled from, that of Paul Ricoeur, Freud and Philosophy: An Essay on Interpretation, trans. Denis Savage (New Haven, Conn.: Yale University Press, 1970), chap. 2, esp. 28.

3 Patrologia Latina, ed. J.-P. Migne, 221 vols. (Paris, 1844-64), 175:635-750, at col. 647. The translation is mine.

4 For typological allegory, see especially Henri de Lubac, Exégèse médiévale: les quatre sens de l'Ecriture, vols. 41, 42, and 59 of Théologie, 2 vols. in 4 (Paris: Aubier, 195964). For neo-Platonic exegesis, see Félix Buffière, Les mythes d'Homère et la pensée grecque, 2nd ed. (1956; Paris: Les Belles Lettres, 1973).

5 Jerome, Epistola ad Damasum, Patrologia Latina, ed. Migne, "Epistola 21," 22:379-94, at col. 385. See also Jerome, "Epistola 70," PL 22:664-68, at col. 665.

6 Sancti Aurelii Augustini de dactrina christiana, libri IV, 3.15.23, ed. Joseph Martin, Corpus Christianorum, Series Latina 32 (Turnhout: Brepols, 1962), 91. Translated as On Christian Doctrine, trans. D. W. Robertson (Indianapolis: Bobbs-Merrill, 1958), 93.

7 Paul de Man, Allegories of Reading: Figural Language in Rousseau, Nietzsche, Rilke, and Proust (New Haven, Conn.: Yale University Press, 1979), 77.

8 J. Hillis Miller, The Etbics of Reading (New York: Columbia University Press, 1987), 59.

9 Ibid, 58 .

10 Cited in P. F. Smith and S. H. Bailey, The Modern English Legal System (London: Sweet and Maxwell, 1984), 240.

11 E. D. Hirsch, Jr., The Aims of Interpretation (Chicago: University of Chicago Press, 1976), 22.

12 J. E. Cross, "On the Allegory of the Seafarer," Medium Aevum 28 (1959): 104-6.

13 The terms are drawn from J. L. Austin, How to Do Things with Words, ed. J. O. Urmson (Cambridge, Mass.: Harvard University Press, 1962). See also Quentin Skinner, "Motives, Intentions, and the Interpretation of Texts," New Literary History 3 (197172): $393-408$.

14 Cited from John Donne, "Meditation 17," in Devotions upon Emergent Occasions, ed. Anthony Rasa (Montreal: McGill-Queen's University Press, 1975), 86-87, at 87.

15 H. P. Grice, "Logic and Conversation," in Speech Acts, ed. Peter Cole and Jerry L. Morgan, Syntax and Semantics, vol. 3 (New York: Academic Press, 1975), 41-58. 
16 The example is taken from Stephen C. Levinson, Pragmatics, Cambridge Textbooks in Linguistics (Cambridge: Cambridge University Press, 1983), 102.

17 Ibid., 109.

18 Ibid., 107.

19 For a powerful yet unpersuasive account that literary discourse is not susceptible to the scrutiny we apply to "ordinary" language, see Barbara Herrnstein Smith, On the Margins of Discourse: The Relation of Literature to Language (Chicago: University of Chicago Press, 1978).

20 For which, in the English context, see Kantik Ghosh, The Wycliffite Heresy: Authority and the Interpretation of Texts, Cambridge Studies in Medieval Literature 45 (Cambridge: Cambridge University Press, 2002), chap. 2. For the pragmatism of Reginald Pecock and Thomas More, see James Simpson, Reform and Cultural Revolution, 13501547, Oxford English Literary History, vol. 2 (Oxford: Oxford University Press, 2002), chap. 9.

21 This last observation drives the project of Hans Georg Gadamer, Truth and Method, 2nd ed., rrans. Joel Weinsheimer and Donald G. Marshall (London: Sheed and Ward, 1989).

22 The Poems of Robert Henryson, ed. Denton Fox (Oxford: Clarendon Press, 1981), 3. All discussion of the editorial issues raised by these lines is indebted to Fox's commentary (190).

23 For an authoritative survey of different approaches to textual criticism that all, nevertheless, require interpretative choices, see G. Thomas Tanselle, "Classical, Biblical, and Medieval Textual Criticism and Modern Editing," in his Textual Criticism and Scholarly Editing (Charlottesville: University Press of Virginia, 1990), 274-321.

24 Charlotte Brewer, "Response," to John M. Bowers, "Piers Plowman's William Langland: Editing the Text, Writing the Author's Life," Yearbook of Langland Studies ? (1995): 65-102, at 92 .

25 William Langland, Piers Plowman: The B-Version; Will's Visions of Piers Plowman, DoWell, Do-Better, and Do-Best, ed. George Kane and E. Talbor Donaldson (London: Athlone Press, 1975), 130.

26 See, for example, Jerome J. McGann, A Critique of Modern Textual Criticism (Chicago: University of Chicago Press, 1983).

27 Alan of Lille, Regulae caelestis iuris, ed. N. M. Häring, in Archives d'histoire doctrinale et littéraire du moyen âge 48 (1981): 97-226, Rule 18 (137).

28 Christopher Norris, Truth and the Ethics of Criticism (Manchester: Manchester University Press, 1994), makes this point very succinctly, arguing that we need to exercise a "principle of charity" as we interpret (17-18). Norris is himself dependent on, yet more lucid than, Donald Davidson, "On the Very Idea of a Conceptual Scheme," in his Inquiries into Truth and Interpretation (Oxford: Clarendon Press, 1984), 183-98: "Charity is forced on us; whether we like it or not, if we want to understand others, we must count them right in most matters" (197).

29 Cicero, De inventione, 2.47.140, ed. H. M. Hubbell (Cambridge, Mass.: Harvard University Press, 1949), 309 .

30 Cicero, De inventione, 2.48.141, ed. Hubbell, 309. 
31 Sec, for example, Paul de Man, Allegories of Reading, chap. 1; and Jacques Derrida, Of Grammatology, trans. Gayatri Chakravorty Spivak (Baltimore: Johns Hopkins University Press, 1976).

32 A point that has also been made by Norris, Truth and the Ethics of Criticism, 15-16.

33 See Ghosh, Wycliffite Heresy, chaps. 1 and 2.

34 Derrida, for example, is an intentionalist in this sense; see Seán Burke, The Death and Return of the Author: Criticism and Subjectivity in Barthes, Foucault, and Derrida (Edinburgh: Edinburgh University Press, 1992), 140-50.

35 Rita Copeland, "Rhetoric and the Politics of the Literal Sense in Medieval Literary Theory: Aquinas, Wyclif, and the Lollards," in Interpretation, Medieval and Modern, ed. Piero Boitani and Anna Torti (Woobridge, Suffolk: D. S. Brewer, 1993), 1-23, at 14.

36 Stanley Fish, "Working on the Chain Gang: Interpretation in Law and Literature," in his Doing What Comes Naturally: Change, Rhetoric, and the Practice of Theory in Literary and Legal Studies (Oxford: Clarendon Press, 1989), 87-102, at 98.

37 Ibid., 97

38 See, for example, Stanley Fish, "Interpreting the Variorum," in his Is There a Text in This Class? The Authority of Interpretative Communities (Cambridge, Mass: Harvard University Press, 1980), 147-80, at 170 .

39 See Norris, Truth and the Ethics of Criticism, 15-16.

40 Fish himself attempts to demolish any such distinction, in "How Ordinary is Ordinary Language," in Is There a Text in This Class? 97-111.

41 Richard Rorty, Contingency, Irony, and Solidarity (Cambridge: Cambridge University Press, 1989), 44.

42 For the juridical senses of author, see M-D. Chenu, "Auctor, actor, autor," Bulletin du Cange 4 (1927): 81-86. For the legal influence of thesis and hypothesis in literary study, in addition to the broader relations between forensic and literary-critical practice, see the brilliant studies by Wesley Trimpi, Muses of One Mind: The Literary Analysis of Experience and lts Continuity (Princeton, N.J.: Princeton University Press, 1983), esp. chap. 10; and Kathy Eden, Poetic and Legal Fiction in the Aristotelian Tradition (Princeton, N.J.: Princeton University Press, 1986).

43 For the relations of forensic torture and truth in ancient Athenian society, see Page DuBois, Torture and Truth (New York: Routledge, 1991).

44 For an example of the way in which psychoanalytic interpretation can be "imperialistic," see David Aers, "Interpreting Dreams: Reflections on Freud, Milton, and Chaucer," in Reading Dreams: The Interpretation of Dreams from Chaucer to Shakespeate, ed. Peter Brown (Oxford: Oxford University Press, 1999), 84-98. 